\title{
Tissue-Specific Superoxide Generation at Interaction Sites in Resistant and Susceptible Near-Isogenic Barley Lines Attacked by the Powdery Mildew Fungus (Erysiphe graminis f. sp. hordei)
}

\author{
Ralph Hückelhoven and Karl-Heinz Kogel \\ Institut für Phytopathologie und Angewandte Zoologie, Ludwigstr. 23, Justus-Liebig-Universität Giessen, \\ D-35390 Giessen, Germany \\ Accepted 1 January 1998.
}

\begin{abstract}
The pathogenesis-related, azide-insensitive generation of superoxide anions $\left(\mathrm{O}_{2}^{-}\right)$was comparatively analyzed in near-isogenic barley (Hordeum vulgare cv. Pallas) lines carrying the powdery mildew (Erysiphe graminis f. sp. hordei) resistance genes Mla12, Mlg, and $\mathrm{mlo5}$, respectively, by the microscopic detection of nitroblue tetrazolium (NBT) reduction to dark blue formazan dyes. These genes govern fungal arrest at different stages of the interaction: (i) at the penetration stage within cell wall appositions (papillae) leaving the attacked cell alive (mlo); (ii) within papillae of cells that subsequently undergo a hypersensitive cell death (HR) (Mlg); or (iii) after penetration by a subsequent HR (Mla12). The susceptible parent line Pallas showed a transient $\mathrm{O}_{2}^{-}$ generation in penetrated epidermal cells at $18 \mathrm{~h}$ after inoculation (hai), whereas epidermal cells of the resistant BCPMla12 produced $\mathrm{O}_{2}^{-}$over a longer time range (by 18 to 36 hai) preceding cell death. No oxidative burst was detected in association with penetration resistance due to effective papillae (BCPMlg and BCPmlo5) although Mlg specified an $\mathrm{HR}$ subsequent to fungal arrest. Hence, $\mathrm{O}_{2}^{-}$ generation in attacked epidermal cells was a result of fungal penetration of the host cell walls and subsequent contact with the host plasma membrane, and not a requirement for $\mathrm{HR}$ elicitation. $\mathrm{O}_{2}^{-}$generation in the mesophyll tissue beneath attacked cells was associated with the response mediated by the genes Mla12 and Mlg. However, only BCPMla12 showed mesophyll cell death. The data indicate that, in barley, $\mathrm{O}_{2}^{-}$accumulation is not a single key determinant of $\mathrm{HR}$ in response to a powdery mildew attack.
\end{abstract}

Additional keyword: radical.

In the early 1980s Doke (1983a) analyzed the role of the superoxide radical in the hypersensitive response (HR) triggered in potato cells after penetration by an avirulent isolate

Corresponding author: Karl-Heinz Kogel, Institut für Phytopathologie und Angewandte Zoologie, Justus-Liebig-Universität Giessen, Ludwigstr. 23, D-35390 Giessen, Germany; Telephone: +49 64199 37490; Fax: +49 64199 37499; E-mail: Karl-Heinz.Kogel@agrar.uni-giessen.de of Phytophthora infestans. Among other compounds, nitroblue tetrazolium (NBT) was used to detect the superoxide radical. Since then, many investigations have been addressed to elucidate the role of $\mathrm{O}_{2}^{-}$and other active oxygen species (AOS) in defense responses and especially in programmed cell death (PCD; Baker and Orlandi 1995; Bolwell et al. 1995; Mehdy 1994; Tenhaken et al. 1995). At the present time, it is quite well accepted that AOS are involved in membrane deterioration (Ádám et al. 1989), cell wall structural protein cross-linking (Bradley et al. 1992; Brisson et al. 1994), development of necrotic lesions (Doke and Ohashi 1988; Jabs et al. 1996), elicitor signal transduction (Nürnberger et al. 1994), induction of cell death (Levine et al. 1994), and probably induced resistance responses (Chen et al. 1993; Neuenschwander et al. 1995; Bi et al. 1995). An azide-insensitive plasma membrane $\mathrm{NAD}(\mathrm{P}) \mathrm{H}$ oxidase, like that responsible for the respiratory burst in mammalian phagocytes (Morel et al. 1991), might be implicated in the HR triggered in plant cells by pathogens. A gene with considerable homology to one encoding a subunit of the mammalian enzyme exists in plants (Groom et al. 1996) and inhibition of the enzyme by diphenyleneiodonium chloride (DPI) affects production of superoxide anions and hydrogen peroxide, and also affects gene activation and cell death in different plant cell cultures and the Arabidopsis thaliana lsdl mutants (Auh and Murphy 1995; Jabs et al. 1996; Levine et al. 1994; Tenhaken et al. 1995). Nevertheless, many controversial reports exist about similarities between PCD in animals and plants (Bestwick et al. 1995; Levine et al. 1996; Wang et al. 1996). NAD(P)H oxidase might participate in signal transduction processes of plant-pathogen interactions (for review see Jones and Dangl 1996; Mehdy 1994), although such a broad claim is questioned by other authors (Bestwick et al. 1997; Bolwell et al. 1995). Arguments against a key role of AOS in defense were provided by Glazener et al. (1996), who showed that Pseudomonas syringae pv. syringae and $P$. fluorescens hrmA mutant strains that were unable to mount an HR in tobacco leaves nevertheless retained the ability to elicit an oxidative burst in cultured cells.

Investigations of the role of AOS in plant defense were mostly done with microbial elicitors and cell or tissue cultures 
of dicot plants. In particular, few data are available for monocots. Therefore, it was our intention to analyze the generation of $\mathrm{O}_{2}^{-}$in the interaction of barley with the powdery mildew fungus (Erysiphe graminis f. sp. hordei, Egh).

We used race A6(290) of Egh, which triggers resistance responses in near-isogenic backcross lines bearing the Mla12, Mlg, or mlo5 genes for powdery mildew resistance. The genes interfere with different stages of fungal development, thereby conferring distinctive interaction phenotypes. While $M l g$ mediates resistance through a papilla response and an HR of the attacked, nonpenetrated epidermal cell (Görg et al. 1993; Schiffer et al. 1997), functional alleles of the Mla locus mediate fungal arrest by mounting an HR only after fungal penetration of the target cell (Kita et al. 1981; Koga et al. 1990) and mlo5 controls a penetration resistance solely due to effective papilla formation (Stolzenburg et al. 1984; Zeyen et al. 1993).

Using NBT, we show here a tissue-specific generation of
$\mathrm{O}_{2}^{-}$at sites of attempted infection is temporally and spatially dependent on the respective plant resistance gene.

\section{RESULTS}

Cytological analysis of the interaction phenotypes mediated by the resistance genes Mla12, Mlg, and mlo5.

The interaction phenotypes mediated by the resistance genes Mla12, Mlg, and mlo5 were cytologically analyzed simultaneously to the local $\mathrm{O}_{2}^{-}$burst in the backcross lines BCPMla12, BCPMlg, and BCPmlo5, and the recurrent parent Pallas. No significant differences in the development of the pathogen were detectable on the four lines before $18 \mathrm{~h}$ after inoculation (hai). By 24 hai, consistent differences were detected. Significantly more germlings had produced haustorial initials on BCPMla12 and Pallas. In approximately $60 \%$ of all interaction sites, a haustorium was seen in the first attacked (living) epidermal cell, while on BCPMlg
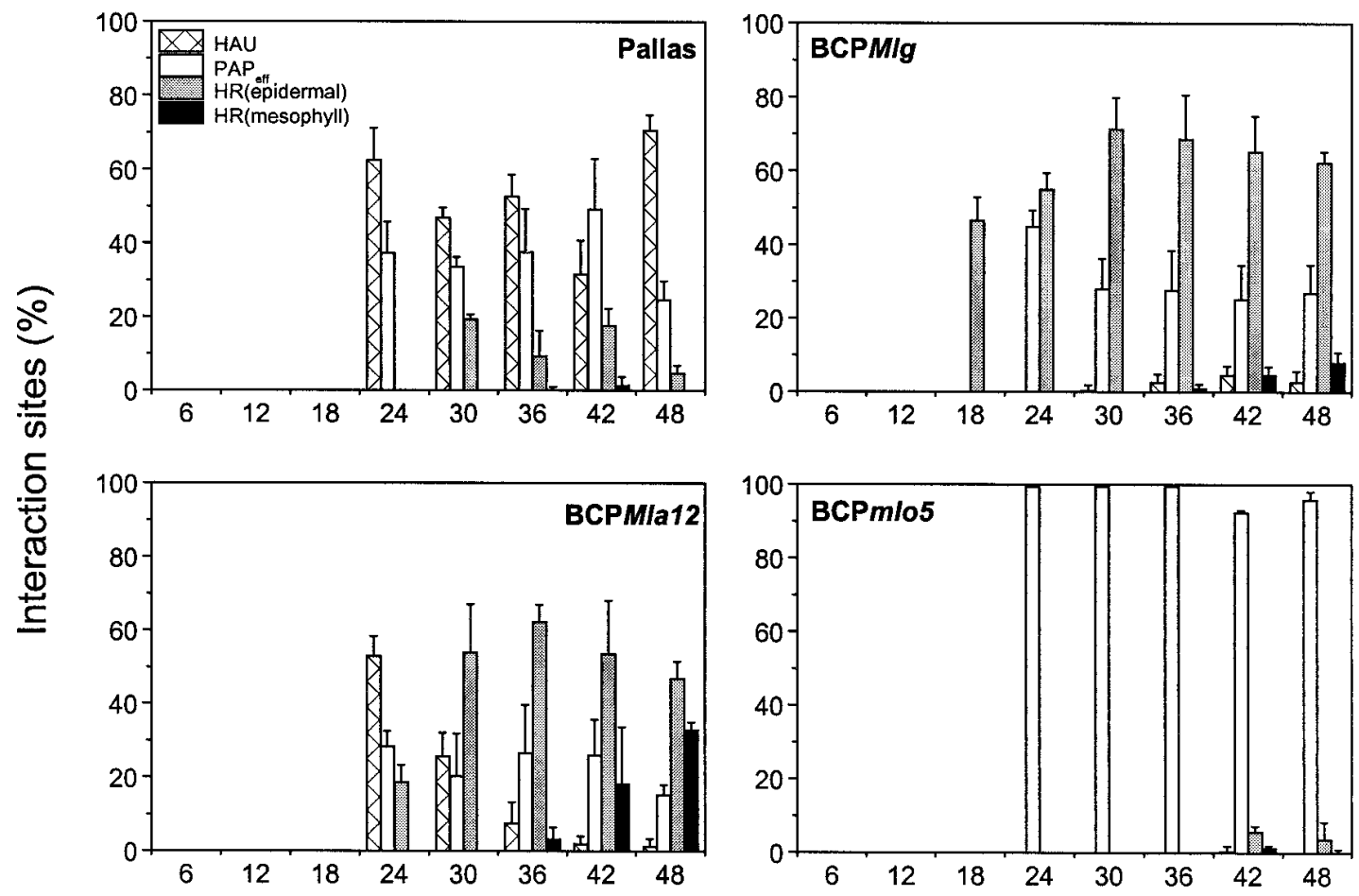

\section{Time after inoculation (h)}

Fig. 1. Defense responses of near-isogenic barley lines carrying different functional powdery mildew resistance genes upon inoculation with Erysiphe graminis f. sp. hordei, race A6. Seven-day-old primary leaves of susceptible recurrent parent Pallas and backcross lines BCPMla12, BCPMlg, and $\mathrm{BCP} m l o 5$, respectively, were inoculated with 10 conidia per $\mathrm{mm}^{2}$ of isolate $\mathrm{A} 6(290)$ and analyzed at early time points during attempted infection. Checkered columns: Frequency of established nondifferentiated or differentiated haustoria in the host cell first attacked by the pathogen. The low values observed from $30 \mathrm{~h}$ after inoculation (hai) onward in BCPMla12 are a result of the increased frequency of penetrated dead cells and of dead mesophyll cells at late time points (gray and black columns). White columns: Frequency of interaction sites restricted to a single host cell in which fungal attack is arrested within a cell wall apposition $\left(\mathrm{PAP}_{\text {eff }}\right)$. None of these infection sites exhibited a hypersensitive response (HR). Dead cells with PAP eff have been evaluated as HRs (gray columns). This leads to an underestimation of this resistance response especially in BCPMlg. Because the time course of fungal penetration into short and long epidermal cell types differs (Koga et al. 1990), only short epidermal cells have been evaluated. Before 24 hai, it was not possible to distinguish between effective and noneffective papillae. Gray columns: Frequency of interaction sites restricted to a single host cell in which attacked cell shows a characteristic yellow whole-cell autofluorescence after excitation with UV light $(\lambda=310 \mathrm{~nm})$. Whole-cell autofluorescence (single-cell HR) is a reliable measure of cell death in the barley-powdery mildew interaction (Koga et al. 1990). No autofluorescent epidermal cells were seen before 18 hai. Black columns: Frequency of interaction sites with mesophyll cells that show a yellow whole-cell autofluorescence (mesophyll HR). No autofluorescent mesophyll cells were seen before 36 hai. In BCPMla12, mesophyll HR was mostly detected in the presence of elongated secondary hyphae. Each column represents average of triplicates of each 100 interaction sites per leaf. Error bars show standard deviations of triplicates. Repetition of experiments led to results very similar to those shown. All together, figure represents evaluation of 19,200 interaction sites. 
and BCPmlo5 haustoria were only rarely observed (Fig. 1). From 30 hai onward, haustoria establishment coincided with the production of elongated secondary hyphae (ESH) that were only occasionally seen on BCPMlg and BCPmlo5 (data not shown). Fungal development on BCPmlo5 was effectively arrested before penetration by highly localized cell wall appositions (effective papillae $\left[\mathrm{PAP}_{\mathrm{eff}}\right]$; Fig. 1). By 24
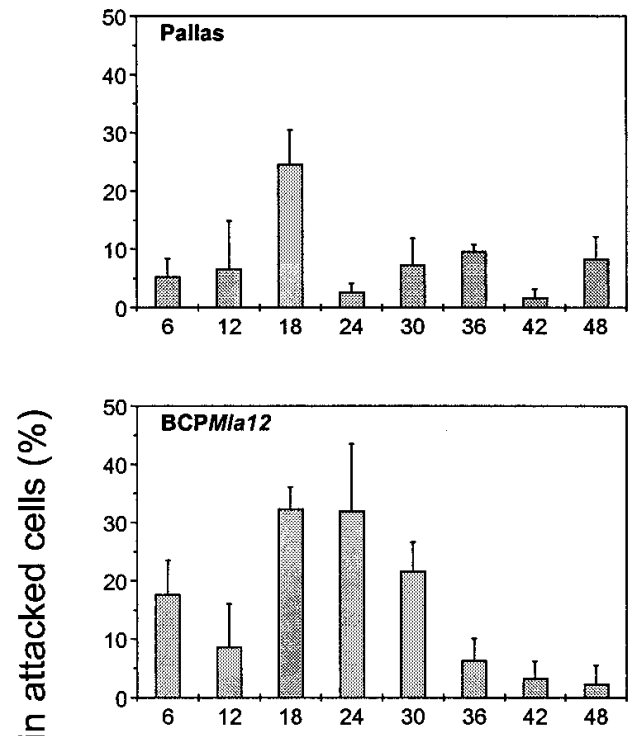

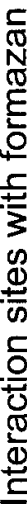
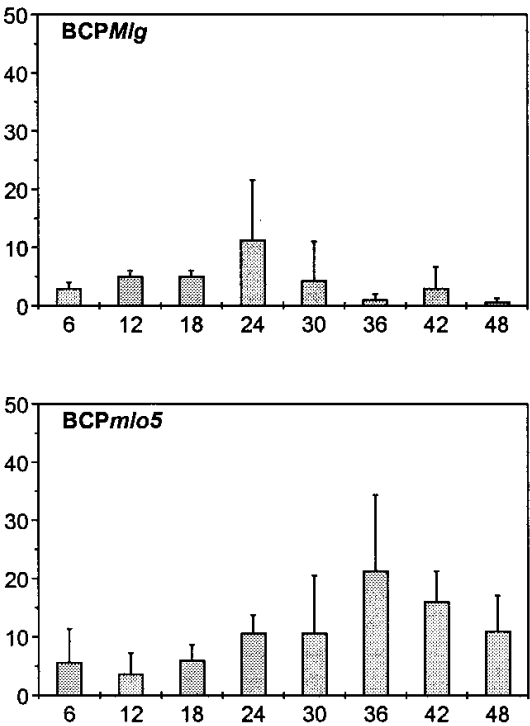

\section{Time after inoculation ( $h$ )}

Fig. 2. Generation of superoxide anions in the epidermal cells of nearisogenic barley lines directly attacked after inoculation with Erysiphe graminis f. sp. hordei, race A6. Seven-day-old primary leaves of susceptible recurrent parent Pallas and backcross lines BCPMla12, $\mathrm{BCPMlg}$, and $\mathrm{BCP} m l o 5$, respectively, were inoculated with 10 conidia per $\mathrm{mm}^{2}$ of isolate A6(290). At indicated time points, leaves were injected with a solution of $0.1 \%$ nitroblue tetrazolium (NBT) and $10 \mathrm{mM}$ $\mathrm{NaN}_{3}$. Subsequently, frequency of interaction sites at which the directly attacked cell showed a formazan stain was microscopically determined. Each column represents average of triplicates of each 100 interaction sites per leaf. Error bars show standard deviations of triplicates. Repetition of experiments led to results very similar to those shown. hai, nearly $100 \%$ of the attacked, living cells had stopped growth within papillae.

In BCPMlg, an HR in directly attacked epidermal cells, as assayed by autofluorescence, was observed as early as 18 hai (Fig. 1). By 30 hai, more than $70 \%$ of the attacked cells had mounted an HR. Importantly, dead cells did not contain a haustorium or a microscopically detectable haustorial initial, strongly suggesting that the $M l g$ gene, like mlo5, mediated a penetration resistance (Görg et al. 1993; Schiffer et al. 1997). In BCPMla12, an HR in attacked epidermal cells was observed from 24 hai onward, i.e., compared with BCPMlg, the onset of HR was delayed by about $6 \mathrm{~h}$. In contrast to BCPMlg, the majority of dead cells in BCPMlal2 contained a haustorium, indicating that, in this case, penetration of epidermal cells is a prerequisite for the elicitation of an HR mediated by Mla12 (Kita et al. 1981; Koga et al. 1990). By 36 hai, more than $60 \%$ of the attacked cells showed an HR. In Pallas, an
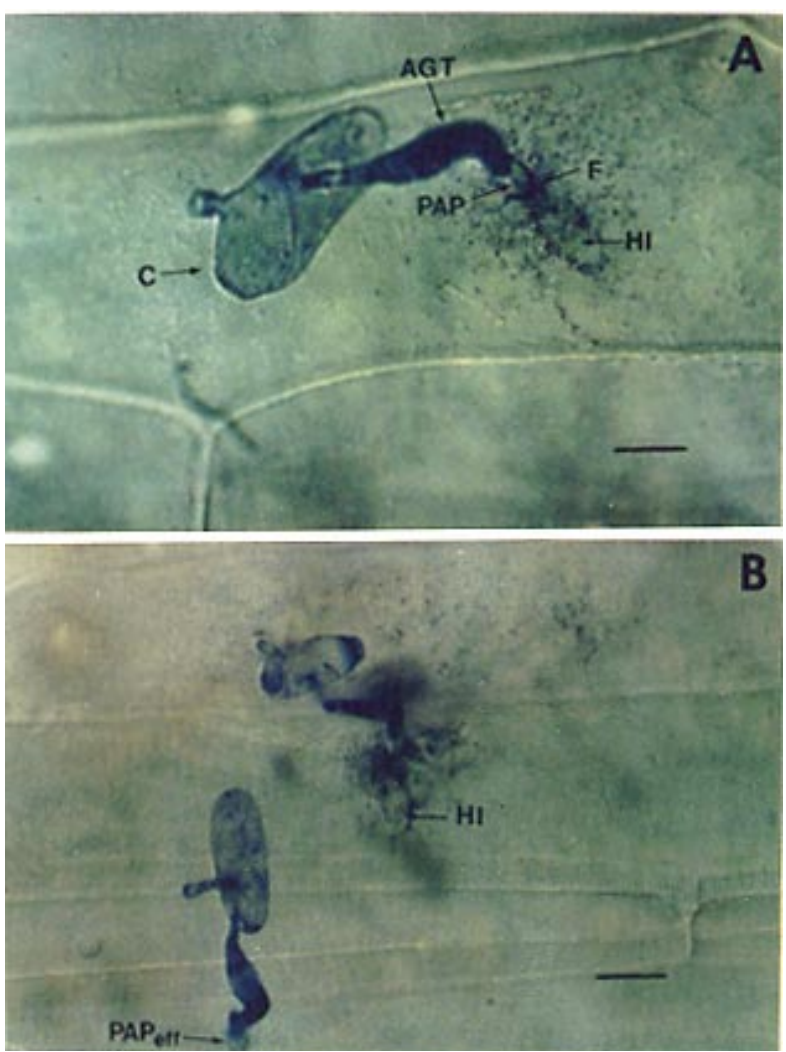

Fig. 3. Microscopic subcellular localization of $\mathrm{O}_{2}^{-}$generation in attacked epidermal cells during resistance response mediated by the Mla12 allele after inoculation with Erysiphe graminis f. sp. hordei, race A6. Seven-day-old barley primary leaves of the line BCPMla12 were inoculated with 10 conidia per $\mathrm{mm}^{2}$ of isolate A6(290). At $24 \mathrm{~h}$ after inoculation (hai), leaves were injected with a solution of $0.1 \%$ nitroblue tetrazolium (NBT) and $10 \mathrm{mM} \mathrm{NaN}_{3}$ and subsequently analyzed microscopically for the accumulation of the blue dye formazan in attacked epidermal cells. A, Interaction site restricted to a single penetrated host cell in which a haustorial initial has been established (24 hai). Formazan dye is visible in association with host plasma membrane and/or cytoplasm in contact with papilla and haustorial initial. AGT, appressorial germ tube, C, conidium, F, formazan dyes, HI, haustorial initial, PAP, papilla. Scale bar $=5 \mu \mathrm{m}$. B, Two interaction sites in close vicinity on same leaf. Superoxide generation is detectable only at site of successful penetration; no dye is found in association with the effective papilla $\left(\mathrm{PAP}_{\text {eff }}\right)$. Scale bar $=8 \mu \mathrm{m}$. 
HR was rarely seen at later interaction stages and BCPmlo5, particularly, showed a very low frequency of cell death.

On BCPMla12, interaction sites with autofluorescent mesophyll cells beneath attacked epidermal cells were seen from 36 hai onward (Fig. 1). The frequency increased with time, reaching $35 \%$ of all sites by 48 hai. Mesophyll HR
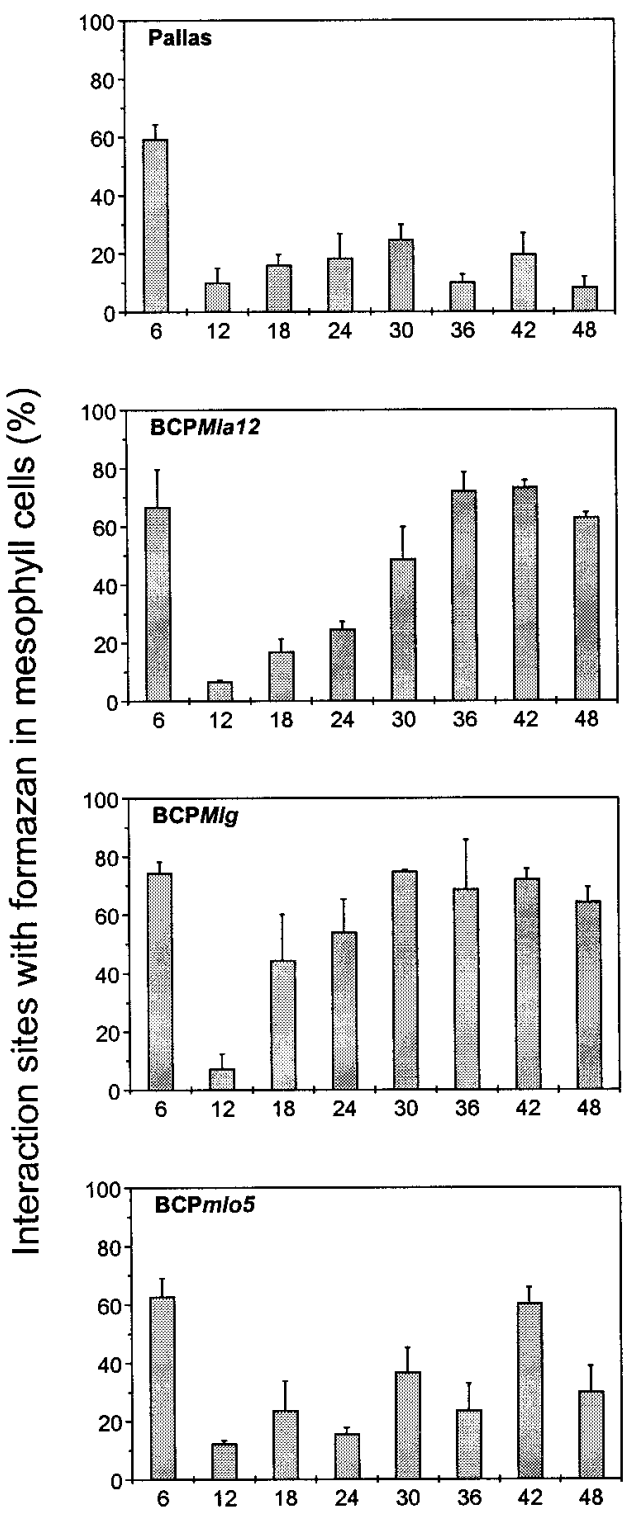

Time after inoculation (h)

Fig. 4. Generation of superoxide anions in mesophyll cells at interaction sites on near-isogenic barley lines after inoculation with Erysiphe graminis f. sp. hordei, race A6. Seven-day-old primary leaves of susceptible recurrent parent Pallas and backcross lines BCPMla12, $\mathrm{BCPMlg}$, and BCPmlo5, respectively, were inoculated with 10 conidia per $\mathrm{mm}^{2}$ of isolate A6(290). At indicated time points, leaves were injected with a solution of $0.1 \%$ nitroblue tetrazolium (NBT) and $10 \mathrm{mM}$ $\mathrm{NaN}_{3}$. Subsequently, frequency of interaction sites with formazanstained mesophyll cells beneath attacked epidermal cells was microscopically determined. Each column represents average of triplicates of each 100 interaction sites per leaf. Error bars show standard deviations of triplicates. Repetition of experiments led to results very similar to those shown. corresponded to ESH development, indicating that mesophyll HR is an Mla12-specified response. In BCPMlg, interaction sites with autofluorescent mesophyll cells were occasionally seen and they were only very rarely observed in BCPmlo5 and Pallas.

\section{Superoxide generation in directly attacked epidermal cells.}

We addressed the question whether different lines show a specific pattern of $\mathrm{O}_{2}^{-}$generation. Because first contact of the fungus with the epidermal host cell determines the outcome of the interaction, we analyzed the $\mathrm{O}_{2}{ }^{-}$response in these cells (Fig. 2). At early interaction stages (0 to 12 hai), when papilla formation beneath the primary and the appressorial germ tube proceeded, the frequency of interaction sites with formazan dyes in epidermal cells was generally low (on average 5\%), except for BCPMla12 showing a frequency of $18 \%$ by 6 hai. By 18 hai, a strong increase in the
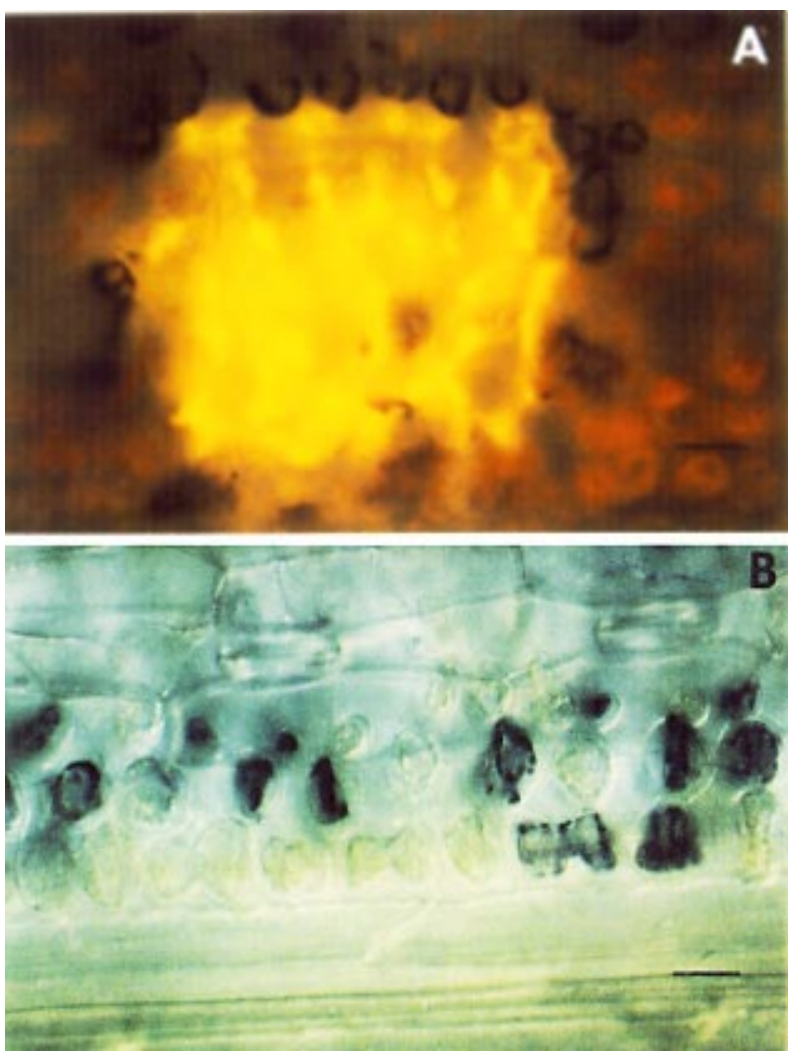

Fig. 5. Microscopic subcellular localization of $\mathrm{O}_{2}^{-}$generation in host mesophyll cells at interaction sites after inoculation with Erysiphe graminis $\mathrm{f}$. sp. hordei, race A6. Seven-day-old barley primary leaves of lines BCPMla12 or BCPMlg were inoculated with 10 conidia per $\mathrm{mm}^{2}$ of isolate A6(290). At $48 \mathrm{~h}$ after inoculation (hai), leaves were injected with a solution of $0.1 \%$ nitroblue tetrazolium (NBT) and $10 \mathrm{mM} \mathrm{NaN}$ and subsequently analyzed microscopically for accumulation of blue dye formazan in mesophyll located beneath an attacked epidermal cell (out of focus). A, BCPMla12: cells in center of picture have collapsed, indicated by yellow autofluorescence. These cells do not show formazan dyes. However, dead cells are surrounded by a ring of cells in which blue dye can be seen. Scale bar $=25 \mu \mathrm{m}$. B, BCPMlg: Formazan dyes accumulate in chloroplasts of mesophyll cells beneath epidermal hypersensitive response. Autofluorescing, dead mesophyll cells were only rarely observed during $M l g$-mediated response. Scale bar $=20 \mu \mathrm{m}$. 
frequency of interaction sites with formazan dyes in attacked epidermal cells was seen in BCPMla12 and Pallas, but not in BCPMlg and BCPmlo5. Thus, enhanced $\mathrm{O}_{2}^{-}$generation temporally and spatially coincided with fungal penetration and haustorium formation, but not with processes resulting in penetration resistance. In BCPMla12, the frequency of interaction sites with stained epidermal cells remained on a high level at 24 hai and slowly declined as epidermal cell death proceeded (30 to 36 hai, see also Figure 1). In Pallas, a high frequency of stained epidermal cells at 18 hai was followed by a strong decline at 24 hai. At later time points (36 to 42 hai), the frequency of stained epidermal cells slightly increased in BCPmlo5.

The subcellular localization of the pathogenesis-related accumulation of formazan dyes in Mla12-mediated resistance is shown in Figure 3. The dark blue color of the formazans was clearly distinguishable from the light blue color of the ink used to stain fungal structures and was also seen when the fungus was not stained with ink (not shown). From 24 hai onward, formazans were mainly detectable at the site of penetration in association with the host plasma membrane and/or cytoplasm around the papilla and the haustorial initial. The body of the papilla was free of dyes (Fig. 3A, shown for 24 hai). Formazans right at the site of penetration were also found in the compatible interaction (Pallas/Egh A6) by 18 hai. Figure $3 \mathrm{~B}$ shows two neighboring interaction sites (24 hai) on a leaf of BCPMla12. At one site, the fungus had successfully penetrated the epidermal cell, forming a haustorial initial. At the second site, fungal development has been arrested by an effective papilla. Formazans were seen only at the site of successful fungal penetration, while no stain was detected in association with the effective papilla, suggesting that penetration is a trigger for $\mathrm{O}_{2}^{-}$generation.

\section{Superoxide generation in mesophyll cells.}

Because previous data showed mesophyll reactions beneath penetrated epidermal cells are an important attribute of Mla resistance (Boyd et al. 1995), we analyzed $\mathrm{O}_{2}^{-}$generation in this tissue. Figure 4 shows the frequency of interaction sites with formazans in mesophyll cells. By contrast to what was

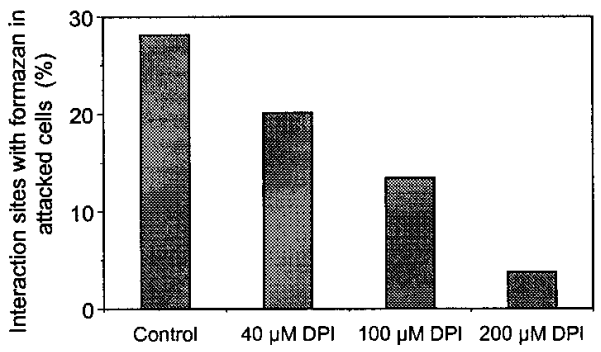

Fig. 6. Inhibition of superoxide generation in directly attacked epidermal cells of BCPMla12 after inoculation with Erysiphe graminis f. sp. hordei, race $\mathrm{A} 6$, with the $\mathrm{NAD}(\mathrm{P}) \mathrm{H}$ oxidase inhibitor diphenyleneiodonium chloride (DPI). Eight-day-old primary leaves were injected with $0,40,100$, and $200 \mu \mathrm{M}$ DPI in $10 \mathrm{mM}$ potassium phosphate buffer, $\mathrm{pH}$ 7.8. Two h later ( $24 \mathrm{~h}$ after inoculation [hai]), leaves were injected with a solution of $0.1 \%$ nitroblue tetrazolium (NBT) and $10 \mathrm{mM} \mathrm{NaN}_{3}$. Subsequently, frequency of attacked epidermal cells being associated with formazan dyes was microscopically determined. Each column represents average of 4 replicates of each 100 interaction sites per leaf. Injection of a mixture of DPI and NBT led to results similar to those shown. observed in attacked epidermal cells, formazan dyes were seen in all four lines by 6 hai. This early response was followed by a strong decline of the frequency by 12 hai. Consistent differences between the four lines were seen from 18 hai onward. At this time, the frequency of sites with stained mesophyll cells was higher in BCPMlg than in the other lines. By 30 hai, nearly $75 \%$ of the interaction sites on BCPMlg showed a response. Dye accumulation in BCPMlg-mesophyll cells corresponded to the presence of an HR in the adjacent attacked epidermal cell (see also Figure 1) but was generally not followed by mesophyll HR. In BCPMla12, $\mathrm{O}_{2}^{-}$generation was somewhat enhanced by 24 hai and drastically increased at later time points, when nearly $75 \%$ of the interaction sites showed formazan dyes in mesophyll cells. In clear contrast to what was found in BCPMlg, $\mathrm{O}_{2}^{-}$generation in BCPMla12 entailed a subsequent mesophyll HR (see also Figure 1). These different responses indicate that the $\mathrm{O}_{2}^{-}$burst is not sufficient for mesophyll cell death.

The subcellular localization of the interaction-related $\mathrm{O}_{2}{ }^{-}$ generation in mesophyll cells of BCPMla12 is shown in Figure 5A. By 48 hai, the mesophyll cells in the center of interaction sites had collapsed. They showed a yellow autofluorescence after excitation with UV light. Dead cells did not contain formazan. However, a band of cells surrounding the necrotic tissue contained the stain mainly associated with chloroplasts. The same type of $\mathrm{O}_{2}^{-}$response was observed in BCPMlg (Fig. 5B) though mesophyll HR was not detected in this genotype.

\section{Superoxide generation in mock-inoculated plants, effects of DPI and darkness.}

Mock inoculation resulted in a pathogenesis-unrelated and genotype-unspecific $\mathrm{O}_{2}^{-}$production in mesophyll cells at early time points $(6 \mathrm{~h}$ after onset of mock treatment, data not shown). Importantly, no mock inoculation-related $\mathrm{O}_{2}^{-}$generation was found at later time points (12 to 48 hai).

We addressed the question whether the pathogenesis-related $\mathrm{O}_{2}{ }^{-}$burst was generated by an $\mathrm{NAD}(\mathrm{P}) \mathrm{H}$ oxidase as demonstrated for mammalian phagocytic cells (for review see Morel et al. 1991). Because DPI was discussed as a reliable "suicide inhibitor" of $\mathrm{NAD}(\mathrm{P}) \mathrm{H}$ oxidase, we used this compound to study its effect on both inhibition of $\mathrm{O}_{2}^{-}$generation and alteration of interaction types. Injection of 40 to $200 \mu \mathrm{M}$ of DPI into leaves of BCPMla12 at 22 hai when the fungus had already penetrated the plant cell wall resulted in a dosedependent reduction of the frequencies of formazan-stained epidermal cells (evaluation at 24 hai; Fig. 6). No effect on fungal development could be detected by this experimental

Table 1. Effect of diphenyleneiodonium chloride (DPI) treatment on fungal growth and epidermal hypersensitive response (HR) in BCPMla12a

\begin{tabular}{|c|c|c|}
\hline \multirow[b]{2}{*}{ Type of reaction } & \multicolumn{2}{|c|}{$\begin{array}{c}\text { Interaction sites } \\
(\% \pm \text { standard deviation }) \\
\end{array}$} \\
\hline & Control & $200 \mu \mathrm{M} D P I$ \\
\hline Haustorial initials & $4.3 \pm 3.3$ & $38.8 \pm 15.8$ \\
\hline Haustoria and elongated secondary hyphae & $43.3 \pm 15.9$ & $1.3 \pm 2.5$ \\
\hline HR (epidermal cells) & $42.3 \pm 11.3$ & $22.3 \pm 8.4$ \\
\hline
\end{tabular}

${ }^{a}$ Injection of DPI at 18 hai; microscopical evaluation at 30 hai. Data represent averages of 4 replicates of each 100 interaction sites per leaf. 
design. At lower concentrations (5 to $20 \mu \mathrm{M}$ ), usually effective to inhibit $\mathrm{NAD}(\mathrm{P}) \mathrm{H}$ oxidase in animal and plant cell cultures as well as in plant tissues (Bestwick et al. 1997; Jabs et al. 1996), an inhibitory effect of DPI on NBT reduction or on the HR was not found (data not shown). Injection of high concentrations of DPI $(200 \mu \mathrm{M})$ into BCPMla12 leaves at 18 hai reduced fungal development, as shown by a lower rate of ESH and epidermal HR, indicating that this high concentration of DPI, in addition to the effect on $\mathrm{O}_{2}^{-}$generation, may have a toxic effect on the fungus (Table 1). Because microscopic studies demonstrated a strong pathogenesis-related $\mathrm{O}_{2}{ }^{-}$burst in the chloroplasts of the mesophyll tissue (see Figure 4), we analyzed the effect of light on pathogenesis-related $\mathrm{O}_{2}^{-}$generation and development of the pathogen (Table 2). BCPMla12 was grown under a 16-h photoperiod and inoculated with Egh A6 7 days after sowing. From 18 hai on, plants were kept in the dark. Under these conditions, all plants showed a tendency for enhanced resistance, as evidenced by a higher frequency of epidermal HR. As a consequence, ESH were formed less frequently. However, pathogenesis-related epidermal $\mathrm{O}_{2}^{-}$production was as high as under a normal photoperiod (data not shown).

The frequency of interaction sites with mesophyll HR was not significantly reduced in the dark. In contrast, pathogenesis-related $\mathrm{O}_{2}^{-}$generation decreased very strongly (from 80 to $31 \%$ of interaction sites). Importantly, $\mathrm{O}_{2}^{-}$generation associated with chloroplasts was completely inhibited. Only some formazan stain outside the chloroplasts that could not be traced back to specific subcellular structures was detectable even after a longer period of darkness (Table 2). The data demonstrate that the chloroplastic $\mathrm{O}_{2}^{-}$burst is not required for mesophyll cell death and that the nonchloroplastic $\mathrm{O}_{2}^{-}$generation does not depend on light.

\section{DISCUSSION}

In this paper, we provide evidence for a host genotypespecific production of superoxide anions at the interaction sites on barley after inoculation with the powdery mildew fungus. A detailed, cell-type-specific, microscopic investigation revealed a pathogenesis-related $\mathrm{O}_{2}^{-}$burst in directly attacked epidermal cells being invaded by a mature or immature

Table 2. Light dependence of infection-related chloroplastic $\mathrm{O}_{2}^{-}$generation in BCPMla12

\begin{tabular}{|c|c|c|}
\hline \multirow[b]{2}{*}{ Type of reaction ${ }^{b}$} & \multicolumn{2}{|c|}{$\begin{array}{c}\text { Interaction sites } \\
(\% \pm \text { standard deviation }) \\
\end{array}$} \\
\hline & Illuminated & $\begin{array}{c}\text { Darkness from } \\
18 \text { hai on }\end{array}$ \\
\hline $\mathrm{ESH}$ & $3.50 \pm 5.92$ & $3.25 \pm 2.36$ \\
\hline $\mathrm{PAP}_{\text {eff }}$ & 12.5 & \\
\hline IR (ep & & \\
\hline & 0 & \\
\hline Formazan dyes in mesophyll cel & $79.75 \pm 4.03$ & $30.50 \pm 12.77$ \\
\hline Formazan dyes in chloroplasts & $79.75 \pm 4.03$ & $0.00 \pm 0.00$ \\
\hline \multicolumn{3}{|c|}{$\begin{array}{l}\text { Superoxide generation as analyzed by formazan formation was micro- } \\
\text { scopically analyzed at } 48 \mathrm{~h} \text { after inoculation (hai) with Erysiphe } \\
\text { graminis f. sp. hordei race A6 in plants that were grown in a 16-h } \\
\text { photoperiod or in the dark from } 18 \text { hai on. Data represent averages of } 4 \\
\text { replicates of each } 100 \text { interaction sites per leaf. } \\
\text { b ESH = elongated secondary hyphae; PAP }{ }_{\text {eff }}=\text { effective papillae; HR = } \\
\text { hypersensitive response. }\end{array}$} \\
\hline
\end{tabular}

haustorium. Such a phenotype was found in the susceptible parent line Pallas as well as in the resistant line BCPMla12 where penetration is a prerequisite for the elicitation of $\mathrm{HR}$. In contrast, no $\mathrm{O}_{2}^{-}$burst was detected at early interaction stages in phenotypes mediated by the Mlg or the mlo5 genes, both governing penetration resistance by effective papillae (Görg et al. 1993; Schiffer et al. 1997; Stolzenburg et al. 1984; Zeyen et al. 1993). Synthesis of papillae commences with an aggregation of the cytoplasm right beneath the tip of the fungal primary germ tube by 3 hai and the appressorium by approximately 10 hai. The papillae formation is usually completed by 5 and 15 hai, respectively (Aist and Bushnell 1991). In this time range, a very low frequency of $\mathrm{O}_{2}^{-}$generation was found in attacked cells. Qualitatively, papillae formation is not dependent on resistance gene function because it occurs to a great extent in all barley cultivars, especially in attacked long epidermal cells (Koga et al. 1990; Kogel et al. 1994). The absence of azide-insensitive $\mathrm{O}_{2}^{-}$generation, just at the time range papillae are formed, suggests that $\mathrm{O}_{2}^{-}$is not directly required for this defense response in barley.

$\mathrm{O}_{2}^{-}$generation temporally and spatially coincided with fungal penetration into epidermal cells. Therefore, our data suggest contact of host plasma membrane with fungal surface structures is the key single-cell event that induced $\mathrm{O}_{2}^{-}$generation in the attacked cells. Because an early albeit very transient burst was detected in Pallas, which lacks any resistance gene corresponding to a functional avr gene in Egh A6, the data may also indicate that elicitation of the $\mathrm{O}_{2}^{-}$burst involves the interaction of race-cultivar nonspecific components. Importantly, race-cultivar specific differences between Pallas and BCPMla12 were seen in the maintenance of the burst once it was triggered: In Pallas, a strong decline of $\mathrm{O}_{2}^{-}$generation was seen in attacked cells by 24 hai, while $\mathrm{O}_{2}^{-}$generation in BCPMla12 remained at a maximal level and declined only slowly at a rate corresponding to an increase in the number of $\mathrm{HR}$ mounting cells. Thus, regulation of $\mathrm{O}_{2}^{-}$production at specific developmental stages of the interaction may be an important factor for the achievement and maintenance of compatibility. Doke (1983b) reported an active suppression of extracellular $\mathrm{O}_{2}^{-}$generation after treatment of potato tuber protoplasts with water-soluble glucans isolated from virulent races of Phytophthora infestans. Similarly, suppressors of HR in wheat leaves were isolated from germ tubes of the rust fungus (Beissmann and Kogel 1992). It is tempting to speculate that such suppressors could also act during compatible interactions of barley with Egh.

One central question of the present study concerned whether azide-insensitive $\mathrm{O}_{2}^{-}$generation at interaction sites is causally required for cell death. Although many reports have shown an involvement of AOS in defense-related processes (Bradley et al. 1992; Jones and Dangl 1996; Levine et al. 1994), an unambiguous proof for AOS as necessary or sufficient for HR is still lacking. Our comparative data based on clearly defined defense phenotypes governed by specific mildew resistance genes suggest that azide-insensitive $\mathrm{O}_{2}^{-}$production is not generally necessary for the elicitation of barley host cell death: First, HR was induced in the initially attacked epidermal cell in both BCPMla12 and BCPMlg, though this response was preceded by $\mathrm{O}_{2}{ }^{-}$accumulation only in the Mla12 backcross line. Because $\mathrm{Mlg}$ mediates fungal growth arrest within papillae, physical contact of host membrane and fungal 
surface structures is needed for the elicitation of $\mathrm{O}_{2}^{-}$generation but not for HR (see also Yahraus et al. 1995). Second, $\mathrm{O}_{2}^{-}$ generation was found in the mesophyll tissue of BCPMlal2 and BCPMlg to an equal extent though mesophyll HR was observed exclusively in the Mla12-resistant line. Third, prevention of chloroplastic superoxide generation in the dark did not significantly affect mesophyll HR.

There is a temporal coincidence between onset of epidermal $\mathrm{HR}$ and subsequent $\mathrm{O}_{2}^{-}$generation in the mesophyll tissue of BCPMla12 and BCPMlg (Figs. 1 and 4). Thus, $\mathrm{O}_{2}^{-}$generation in the mesophyll seems to be a consequence of cell death in adjacent epidermal cells. Secondary metabolites and $\mathrm{H}_{2} \mathrm{O}_{2}$ from HR-mounting epidermal cells might block the photosynthetic electron transport in the neighboring mesophyll cells, leading to enhanced light-dependent superoxide generation via ferredoxin/ $\mathrm{NAD}(\mathrm{P}) \mathrm{H}$ oxidoreductase (Mehler reaction: Elstner and Osswald 1994; Polle 1996).

Our data are also consistent with the hypothesis that $\mathrm{O}_{2}^{-}$ generation in cells adjacent to cells mounting an HR is a signal preventing cells from ongoing cell death, as suggested for Arabidopsis thaliana (Jabs et al. 1996). Similarly, Levine et al. (1994) showed that $\mathrm{H}_{2} \mathrm{O}_{2}$ not only acts as a trigger for HR but also activates genes encoding enzymes that prevent cells from oxidative damage. Thus, AOS at interaction sites may have different roles as players in the elicitation or prevention of cell death depending on their concentration, subcellular localization, and duration of the burst. To this end, the $\mathrm{O}_{2}^{-}$generation in epidermal cells of BCPmlo5 at late interaction stages (30 to 42 hai; Fig. 2) may be interpreted as a signal preventing attacked cells from cell death after the fungus has been stopped by effective papillae though it cannot be excluded that cell death occurs in attacked cells at late time points not evaluated in our experiments.

\section{Possible sources of epidermal $\mathrm{O}_{2}^{-}$generation.}

Doke (1983a) reported the detection of pathogenesis-related $\mathrm{O}_{2}^{-}$generation and the possible involvement of azideinsensitive $\mathrm{NAD}(\mathrm{P}) \mathrm{H}$ oxidase in $\mathrm{HR}$. Inoculation of potato tuber tissue disks with an avirulent race of Phytophthora infestans was accompanied by enhanced superoxide dismutase (SOD) sensitive reduction of both NBT and cytochrome c. Since then, several groups have shown that NBT reduction is a suitable probe for $\mathrm{O}_{2}^{-}$generation in vivo (Ádám et al. 1989; Doke and Ohashi 1988; Jabs et al. 1996). The superoxide radical reduces NBT by several one-electron reducing steps to formazan and further to diformazan (Auclair and Voisin 1985). The design of our experiments focused on $\mathrm{O}_{2}^{-}$production not being prevented by $\mathrm{NaN}_{3}$. Thus, we cannot exclude that $\mathrm{O}_{2}^{-}$generated by azide-sensitive systems like peroxidases or cytochrome c oxidase might play a role in cell death (Bolwell et al. 1995; Gross et al. 1977).

In our experiments, DPI, an inhibitor of the NAD(P)H oxidase, affected $\mathrm{O}_{2}^{-}$generation in attacked epidermal cells when applied in concentrations up to 10-fold of those effective in other systems (Fig. 6; Bestwick et al. 1997; Jabs et al. 1996). No effect of the inhibitor on chloroplastic $\mathrm{O}_{2}^{-}$generation in the mesophyll was observed (data not shown). Epidermal HR in BCPMla12 was inhibited by $200 \mu \mathrm{M}$ DPI when injected 12 $\mathrm{h}$ before the onset of cell death (Table 1). At this concentration, a toxic effect on the plant and/or the fungus cannot be excluded (see Table 1). Because suppression of the epidermal
$\mathrm{HR}$ did not result in a compatible interaction, the reduced $\mathrm{O}_{2}^{-}$ generation after DPI treatment (Fig. 6) could also be a result of a reduced haustorial pressure due to the arrest of haustorium development rather than a specific inhibition of $\mathrm{NAD}(\mathrm{P}) \mathrm{H}$ oxidase.

The low DPI sensitivity of epidermal NBT reduction and cell death (Fig. 6 and Table 1) points to a so-far-unidentified $\mathrm{O}_{2}^{-}$generating system in barley attacked by Egh being different from those DPI- and azide-sensitive systems described in lettuce and Arabidopsis thaliana lsdl mutants (Bestwick et al. 1997; Jabs et al. 1996).

The present data are in accord with those of Naton et al. (1996), who showed that HR of cultured parsley cells is insensitive to extracellular AOS scavengers like superoxide dismutase, catalase, or ascorbate. Interestingly, injection of SOD and catalase into BCPMla12 failed to inhibit HR. Similarly, we excluded lipoxygenases as effectors of HR and NBT reduction by applying the inhibitors ibuprofen and piroxicam (data not shown).

A recent study by the Lamb group (Levine et al. 1994) suggested that $\mathrm{H}_{2} \mathrm{O}_{2}$ from the oxidative burst drives several plant defense responses, including the cross-linking of cell wall structural proteins (Bradley et al. 1992). Accumulation of oxalate oxidase has been reported in interactions of barley with the powdery mildew fungus (Zhang et al. 1995). By catalyzing oxalate oxidation, this enzyme leads to $\mathrm{H}_{2} \mathrm{O}_{2}$ production. Thus, further work must show whether AOS different from $\mathrm{O}_{2}^{-}$or azide-sensitive $\mathrm{O}_{2}^{-}$sources could be causally required for papillae formation and cell death.

\section{MATERIALS AND METHODS}

\section{Plants, pathogens, and inoculation.}

The barley (Hordeum vulgare L.) cv. Pallas and the mlo5, $M l g$, and Mla12 backcross lines in Pallas were obtained from Lisa Munk (Copenhagen). Their generation has been described previously (Kølster et al. 1986). Plants were grown in a growth chamber at $16^{\circ} \mathrm{C}, 60 \%$ relative humidity, and a photoperiod of $16 \mathrm{~h}\left(100 \mu \mathrm{E} \cdot \mathrm{s}^{-1} \cdot \mathrm{m}^{-2}\right)$. Inoculation was done with 10 conidia $\mathrm{mm}^{-2}$ from Erysiphe graminis f. sp. hordei, race A6 (Wiberg 1974) on the seventh day after germination. The fungus was cultivated on Golden Promise according to Kogel et al. (1994).

\section{Detection of the superoxide anions.}

The solution for the histochemical detection of $\mathrm{O}_{2}^{-}$contained $0.1 \% \mathrm{NBT}(\mathrm{wt} / \mathrm{vol})$ and $10 \mathrm{mM} \mathrm{NaN}_{3}$ in $10 \mathrm{mM}$ potassium phosphate buffer, pH 7.8 (Ádám et al. 1989). At the indicated time points, the solution was injected into the primary leaves of barley seedlings. NBT-treated plants were kept for 30 min under daylight and subsequently harvested by cutting the infiltrated region of the leaves and placing them in a clearance solution $(0.15 \%$ trichloroacetic acid [wt/vol] in ethylalcohol:chloroform [4:1; vol/vol]). The solution was exchanged once during the next $48 \mathrm{~h}$ of incubation. Subsequently, leaves were stored in $50 \%$ glycerol. To stain fungal structures for bright-field microscopy, leaves were incubated in $10 \%$ blue ink (vol/vol, Pelikan, Hanover, Germany) within $25 \%$ acetic acid for $1 \mathrm{~min}$ and then washed to remove the excess ink. Whole-cell and papilla autofluorescence was observed by fluorescence microscopy (excitation filter $485 \mathrm{~nm}$, 
dichoric mirror $510 \mathrm{~nm}$, barrier filter $520 \mathrm{~nm}$ ). All microscopy was done with an Axioplan microscope (Zeiss, Jena, Germany). One hundred or more attacked short cells (type A and type B of the adaxial epidermis; Koga et al. 1990) were scored per primary leaf.

\section{DPI treatment.}

BCPMla12 plants were injected with different concentrations of DPI (Alexis, Grünberg, Germany) dissolved in 10 $\mathrm{mM}$ potassium phosphate buffer, $\mathrm{pH}$ 7.8.

\section{ACKNOWLEDGMENTS}

The work was supported by the Bundesministerium für Bildung, Wissenschaft Forschung und Technologie (BMBF), Bonn.

\section{LITERATURE CITED}

Ádám, A., Farkas, T., Somlyai, G., Hevesi, M., and Király, Z. 1989. Consequence of $\mathrm{O}_{2}^{-}$generation during a bacterially induced hypersensitive reaction in tobacco: Deterioration of membrane lipids. Physiol. Mol. Plant Pathol. 34:13-26.

Aist, J. R., and Bushnell, W. R. 1991. Invasion of plant hosts by powdery mildew fungi and cellular mechanism of resistance. Pages 321345 in: The Fungal Spore and Disease Initiation in Plants and Animals. G. T. Cole and H. C. Hoch, eds. Plenum Press, New York.

Auclair, C., and Voisin, E. 1985. Nitroblue tetrazolium reduction. Pages 123-132 in: CRC Handbook of Methods of Oxygen Radical Research. R. A. Greenwald, ed. Boca Raton, FL.

Auh, C.-K., and Murphy, T. M. 1995. Plasma membrane redox enzyme is involved in the synthesis of $\mathrm{O}_{2}^{-}$and $\mathrm{H}_{2} \mathrm{O}_{2}$ by Phytophthora elicitorstimulated rose cells. Plant Physiol. 107:1241-1247.

Baker, C. J., and Orlandi, E. W. 1995. Active oxygen in plant pathogenesis. Annu. Rev. Phytopathol. 33:299-321.

Beissmann, B., and Kogel, K. H. 1992. Identification and characterization of suppressors. Pages 259-275 in: Modern Methods in Plant Analysis, N.S. Vol. 13. H. F. Linskens and J. F. Jackson, eds. Springer, Berlin.

Bestwick, C. S., Bennett, M. H., and Mansfield, J. W. 1995. Hrp mutant of Pseudomonas syringae pv phaseolicola induces cell wall alterations but not membrane damage leading to the hypersensitive reaction in lettuce. Plant Physiol. 108:503-516.

Bestwick, C. S., Brown, I. R., Bennett, M. H. R., and Mansfield, J. W. 1997. Localization of hydrogen peroxide accumulation during the hypersensitive reaction of lettuce cells to Pseudomonas syringae pv phaseolicola. Plant Cell 9:209-221.

Bi, J.-M., Kenton, P., Mur, L., Darby, R., and Draper, J. 1995. Hydrogen peroxide does not function downstream of salicylic acid in the induction of PR protein expression. Plant J. 8:235-246.

Bolwell, G. P., Butt, V. S., Davies, D. R., and Zimmerlin, A. 1995. The origin of the oxidative burst in plants. Free Rad. Res. 23:517-532.

Boyd, L. A., Smith, P. H., Foster, E. M., and Brown, K. M. 1995. The effects of allelic variation at the Mla resistance locus in barley on the early development of Erysiphe graminis f.sp. hordei and host responses. Plant J. 7:959-968.

Bradley, D. J., Kjellbom, P., and Lamb, C. J. 1992. Elicitor- and woundinduced oxidative cross-linking of a proline-rich plant cell wall protein: A novel rapid defense response. Cell 70:21-30.

Brisson, L. F., Tenhaken, R., and Lamb, C. 1994. Function of oxidative cross-linking of cell wall structural proteins in plant disease resistance. Plant Cell 6:1703-1712.

Chen, Z., Silva, H., and Klessig, D. F. 1993. Active oxygen species in the induction of plant acquired resistance by salicylic acid. Science 262:1883-1885.

Doke, N. 1983a. Involvement of superoxide anion generation in the hypersensitive response of potato tuber tissues to infection with an incompatible race of Phytophthora infestans and to the hyphal wall components. Physiol. Plant Pathol. 23:345-357.

Doke, N. 1983b. Generation of superoxide anion by potato tuber protoplasts during the hypersensitive response to hyphal wall components of Phytophthora infestans and specific inhibition of the reaction by suppressors of hypersensitivity. Physiol. Plant Pathol. 23:359-367.

Doke, N., and Ohashi, Y. 1988. Involvement of an $\mathrm{O}_{2}^{-}$generating system in the induction of necrotic lesions on tobacco leaves infected with tobacco mosaic virus. Physiol. Mol. Plant Pathol. 32:163-175.

Elstner, E. F., and Osswald, W. 1994. Mechanisms of oxygen activation during plant stress. Proc. R. Soc. Edinburgh Sect. B. 102:131-154.

Glazener, J. A., Orlandi, E. W., and Baker, C. J. 1996. The active oxygen response of cell suspensions to incompatible bacteria is not sufficient to cause hypersensitive cell death. Plant Physiol. 110:759-763.

Görg, R., Hollricher, K., and Schulze-Lefert, P. 1993. Functional analysis and RFLP-mediated mapping of the Mlg resistance locus in barley. Plant J. 3:857-866.

Groom, Q. J., Torres, M. A., Fordham-Skelton, A. P., Hammond-Kosak, K. E., Robinson, N. J., and Jones, J. D. G. 1996. RbohA, a rice homologue of mammalian gp91phox respiratory burst oxidase gene. Plant J. 10:515-522.

Gross, G. G., Janse, C., and Elstner, E. F. 1977. Involvement of malate, monophenols, and the superoxide radical in hydrogen peroxide formation by isolated cell walls from horseradish (Armoracia lapathifolia Gilib.). Planta 136:271-276.

Jabs, T., Dietrich, R. A., and Dangl, J. L. 1996. Initiation of runaway cell death in an Arabidopsis mutant by extracellular superoxide. Science 273:1853-1856.

Jones, A. M., and Dangl, J. L. 1996. Logjam at the Styx: Programmed cell death in plants. Trends Plant Sci. 1:114-118.

Kita, N., Toyoda, H., and Shishiyama, J. 1981. Chronological analysis of cytological responses in powdery-mildewed barley leaves. Can. J. Bot. 59:1761-1768.

Koga, H., Bushnell, W. R., and Zeyen, R. J. 1990. Specificity of cell type and timing of events associated with papilla formation and the hypersensitive reaction in leaves of Hordeum vulgare attacked by Erysiphe graminis f.sp. hordei. Can. J. Bot. 68:2344-2352.

Kogel, K. H., Beckhove, U., Dreschers, J., Münch, S., and Rommé, Y. 1994. Acquired resistance in barley: The resistance mechanism induced by 2,6-dichloroisonicotinic acid is a phenocopy of a genetically based mechanism governing race-specific powdery mildew resistance. Plant Physiol. 106:1269-1277.

Kølster, P., Munk, L., Stølen, O., and Løhde, J. 1986. Near-isogenic barley lines with genes for resistance to powdery mildew. Crop Sci. 26:903-907.

Levine, A., Pennell, R. I., Alvarez, M. E., Palmer, R., and Lamb, C. 1996. Calcium-mediated apoptosis in a plant hypersensitive disease resistance response. Curr. Biol. 6:427-437.

Levine, A., Tenhaken, R., Dixon, R., and Lamb, C. 1994. $\mathrm{H}_{2} \mathrm{O}_{2}$ from the oxidative burst orchestrates the plant hypersensitive disease resistance response. Cell 79:583-593.

Mehdy, M. C. 1994. Active oxygen species in plant defense against pathogens. Plant Physiol. 105:467-472.

Morel, F., Doussiere, J., and Vignais, P. V. 1991. The superoxidegenerating oxidase of phagocytic cells: Physiological, molecular and pathological aspects. Eur. J. Biochem. 201:523-546.

Naton, B., Hahlbrock, K., and Schmelzer, E. 1996. Correlation of rapid cell death with metabolic changes in fungus infected, cultured parsley cells. Plant Physiol. 112:433-444.

Neuenschwander, U., Vernooij, B., Friedrich, L., Uknes, S., Kessmann, H., and Ryals, J. 1995. Is hydrogen peroxide a second messenger of salicylic acid in systemic acquired resistance? Plant J. 8: 227-233.

Nürnberger, T., Nennstiel, D., Jabs, T., Sacks, W. R., Hahlbrock, K., and Scheel, D. 1994. High affinity binding of a fungal oligopeptide elicitor to parsley plasma membranes triggers multiple defense responses. Cell 78:449-460.

Polle, A. 1996. Mehler reaction: Friend or foe in photosynthesis? Bot. Acta 109:84-89.

Schiffer, R., Görg, R., Jarosch, B., Beckhove, U., Bahrenberg, G., Kogel, K.-H., and Schulze-Lefert, P. 1997. Tissue dependence and differential cordycepin sensitivity of race-specific resistance responses in the barley-powdery mildew interaction. Mol. Plant-Microbe Interact. 10: 830-839.

Stolzenburg, M. C., Aist, J. R., and Israel, H. W. 1984. The role of papillae in resistance to powdery mildew conditioned by the $m l-o$ gene in barley. I. Correlative evidence. Physiol. Plant Pathol. 25: 337-346. 
Tenhaken, R., Levine, A., Brisson, L. F., Dixon, R. A., and Lamb, C. 1995. Function of the oxidative burst in hypersensitive disease resistance. Proc. Nat. Acad. Sci. USA 92:4158-4163.

Wang, H., Li, J., Bostock, R. M., and Gilchrist, D. G. 1996. Apoptosis: A functional paradigm of programmed plant cell death induced by a host-selective phytotoxin and invoked during development. Plant Cell 8:375-391.

Wiberg, A. 1974. Genetical studies of spontaneous sources of resistance to powdery mildew in barley. Hereditas 77:89-148.

Yahraus, T., Chandra, S., Legendre, L., and Low, P. S. 1995. Evidence for a mechanically induced oxidative burst. Plant Physiol. 109:12591266.

Zeyen, R. J., Ahlstrand, G. G., and Carver, T. L. W. 1993. X-ray microanalysis of frozen-hydrated, freeze-dried, and critical point dried leaf specimens: Determination of soluble, and insoluble chemical elements at Erysiphe graminis epidermal cell papilla sites in barley isolines containing $\mathrm{Ml}-\mathrm{o}$ and $\mathrm{ml}-\mathrm{o}$ alleles. Can. J. Bot. 71:284-296.

Zhang, Z., Collinge, D. B., and Thordal-Christensen, H. 1995. Germinlike oxalate oxidase a $\mathrm{H}_{2} \mathrm{O}_{2}$-producing enzyme accumulates in barley attacked by the powdery mildew fungus. Plant J. 8:139-145. 